\title{
Apaisado Profundo, un documental sobre Beatriz Vallejos
}

\author{
Alicia Acosta \\ Grupo de realizadores audiovisuales \\ independientes Cienvolando
}

Estas dos palabras iniciales, que com- favoreció un abundante intercambio ponen uno de los poemas más breves artístico y epistolar. de Beatriz Vallejos (Atardece / Apaisado El filme se logra luego de varios años profundo), dan nombre al documental de recopilación de material y búsquedas realizado por el grupo Cienvolando ${ }^{1}$ sobre la reconocida poeta y laquista santafesina fallecida en 2007. narrativas y estéticas. Sin embargo, el registro del homenaje de despedida realizado a la poeta en su vieja casona de San

El equipo de realizadores audiovisuales recoge la iniciativa de la autora de esta reseña basada en la prolongada amistad que sostuviera con la poeta, lo que le permitió participar de su intimidad y José del Rincón, en mayo de 2008 (a casi un año de su fallecimiento) fue el paso inicial hacia la concreción del proyecto, llevado a cabo con el apoyo del Fondo Nacional de las Artes.

1. Cienvolando es un grupo de realizadores independientes cuya idea es propiciar un espacio de taller donde se articulen experiencias de aprendizaje e investigación y la producción de obras. Los equipos de trabajo pueden ir variando de acuerdo con los proyectos en marcha; pero como principio organizativo y como voluntad artística favorecen un trabajo grupal que replantee la tradicional figura del director y fundamentalmente que potencie el cruce y enriquecimiento de miradas desde generaciones diversas 


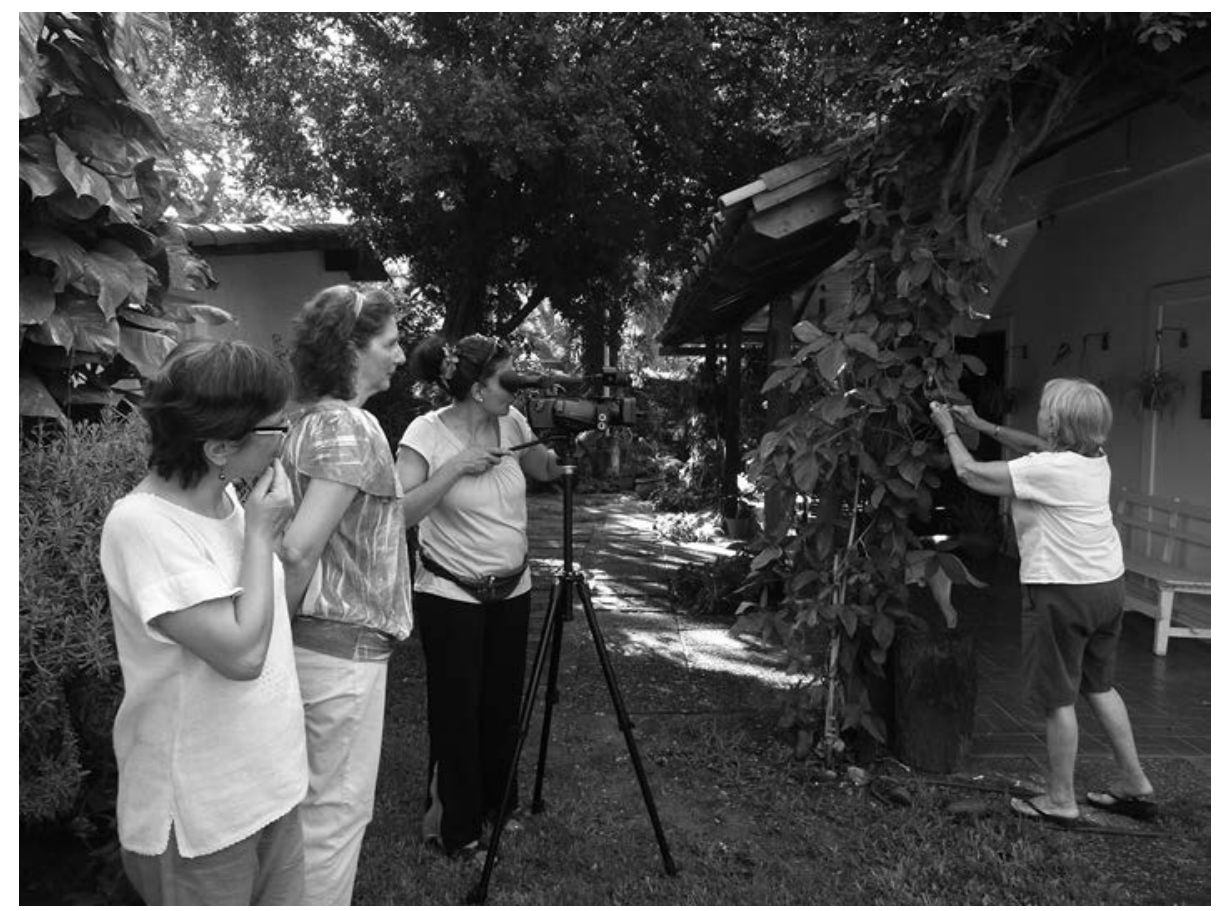

Acosta, Cherry y Masat preparan toma a Kiki Demiryi. Foto: José Cettour.

El documental es un intento de acercamiento a la esencial espiritualidad de Vallejos desde su propia voz, la recreación de su ambiente natural en San José del Rincón y la palabra de algunos amigos y vecinos. Suscribiendo una deliberada estética de la lentitud, Cienvolando elige una cámara observadora y muda, como un ojo que acaricia y habla el lenguaje moroso de los movimientos de la poeta. El registro documental se mueve dentro de un estrecho círculo: la casa en Rincón, el patio circundante, las cuadras de alrededor, el río. La voz en off de Beatriz dice algunos poemas en momentos estratégicos y se suma a la de los habitantes del paisaje inmediato. Se obvia el comentario docto, académico, acerca de su vida y de su obra. Lo que se sabe sobre Beatriz Vallejos lo dicen esos pocos elementos íntimos a través del ojo de la cámara.

La película se asume como un poema audiovisual que recoge la presencia a través de la ausencia, sugiriendo que el mundo interior de Vallejos era amplio, aireado, cósmico, sobre todo desde que definitivamente se radicara en San José del Rincón, su lugar elegido. La palabra poé- 


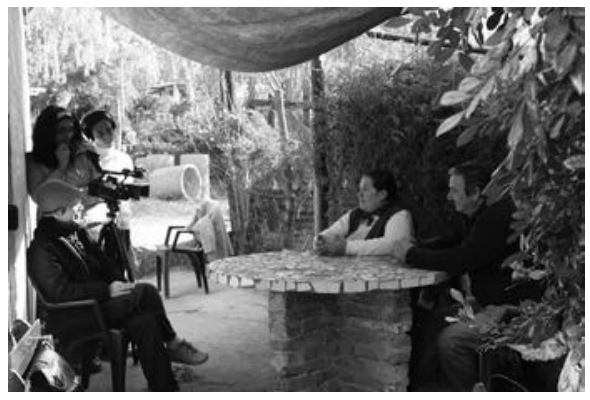

Acosta, Masat y Rondina en entrevista a la familia Osuna. Foto: José Cettour.

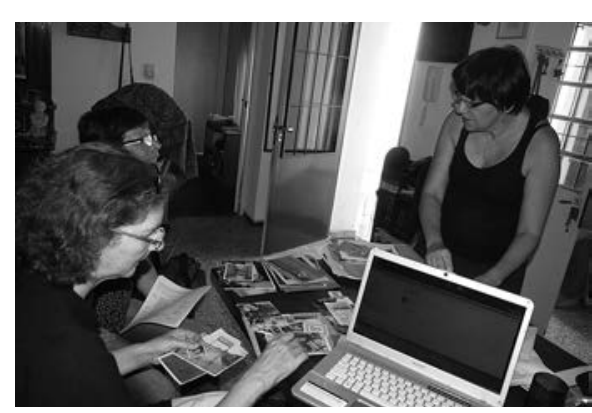

Cherry y Acosta revisan fotos con Elena Rigatuso, hija de Beatriz. Foto: José Cettour. tica de Vallejos convoca al silencio. Desde el lenguaje del cine Cienvolando busca traducir ese silencio. Sus poemas son poemas de interioridad, llevan a la reflexión, al ensimismamiento. El documental busca sintonizar su ritmo con aquel otro.

Apaisado profundo es, antes que un homenaje, la elaboración de vivencias compartidas, imágenes interiores que toman cuerpo, un rescate en la memoria y de la memoria.
Este filme fue declarado de interés por la Comuna de San José del Rincón, el Honorable Concejo Deliberante de la Municipalidad de Santa Fe y la Legislatura Provincial. El estreno se realizó el 6 de octubre de 2012 en el Museo de la Costa de San José de Rincón, co-organizado con la Asociación local Amigos por la Cultura. Le siguieron las presentaciones en el Museo de Arte Contemporáneo de la ciudad de Santa Fe el I6 de noviembre de 20I2, y en la Sede de AMSAFE Rosario el 30 de noviembre de 2012. 
Ficha técnica Apaisado profundo

- Documental, 43', 2012.

- Alicia Acosta: idea, investigación, guión.

- José Cettour: guión, cámara, sonido, foto fija.

- Teresita Cherry: guión, cámara, edición.

- Mercedes Rondina: captura y posproducción de sonido.

- Maricel Masat: cámara.

- Jorge Diego Vázquez: música original y guitarra rítmica en el tema Apaisado profundo.

- Emiliano Beltzer: posproducción de sonido.

- Ana Sol Alonso: retoque fotográfico y diseño.

- Diana Guastavino: comunicación.

- Iván Gutierrez Cachullián: bandoneón.

- Guillermo Rubelt: guitarra.

- Darío Javier Balderramo: percusión.

- Pedro Vilte: grabación.

- Testimonios de: Kiki Demiryi, Bety y Edgardo Osuna, Chela Zarza, Mario Miño.

- Producción general: grupo Cienvolando, con el apoyo del Fondo Nacional de las Artes (Beca para proyectos grupales).

- Sitios Web de información sobre el documental, el grupo de realizadores y su filmografía:

http://apaisadoprofundo.wix.com/documental http://cienvolandotaller.wix.com/audiovisual 